\title{
É HORA DE MUDARMOS DE VIA: LIÇÕES DO CORONAVÍRUS
}

\author{
Paulo Sergio de Oliveira Junior ${ }^{1}$ \\ Instituto Sedes Sapientiae
}

MORIN, Edgar. É hora de mudarmos de via: lições do coronavírus. Colaboração de Sabah Abquessalam. Tradução de Ivone Castilho Benedetti. 2 ed. Rio de Janeiro: Bertrand Brasil, 2021.

"Sou cria de todas as crises que meus 99 anos viveram."

(Edgar Morin)

Ler o mais recente livro de Edgar Morin que aborda a humanidade diante da pandemia da Covid19 é ver-se como um agente desse evento histórico e mundial tão presente em nossas vidas. É impossível esquecer-se de que estamos vivendo uma pandemia: o número crescente de mortos, avanços e retrocessos das vacinas, o protocolo de saúde e segurança, bem como as tentativas de boicote a campanhas de prevenção e de vacinação, minimizando os efeitos do vírus letal.

Em É hora de mudarmos de via, Morin reflete sobre os impactos do coronavírus, relacionando-os às crises de ordem planetária que surgiram com o advento da modernidade. Em seu "Preâmbulo", entramos em contato com o idealizador do pensamento complexo, acompanhando-o numa sucessão de fatos históricos atrelados à vida pessoal, do nascimento até hoje. Morin, na altura dos seus 100 anos, resgata a origem familiar, a trajetória dos pais que presenciaram a gripe espanhola no começo do século XX, estabelecendo relações de causa e consequência. "Esses acontecimentos perturbadores me transformaram e formaram" (MORIN, 2021, p. 12), declara o escritor francês que, humildemente, apresentou eventos os quais não compreendia quando jovem.

Ainda nesse trecho do texto, tomamos conhecimento das escolhas ideológicas do autor, que valoriza uma posição inteligível quanto às concepções de Homem, Sociedade e História. A característica marcante de Morin é estar aberto a rever essas escolhas. Nas palavras do autor: "tirei (...) a lição de me defender de quaisquer derivas, de manter em mim a vigilância crítica e autocrítica, de revisar minhas ideias quando sobrevenham novas experiências históricas" (MORIN, 2021, p. 14). A forma como apresenta os eventos históricos, associando razão à sensibilidade, é uma das marcas de seu pensamento complexo. Assim, da mesma forma como valoriza a juventude com sua autonomia e ideias revolucionárias, reconhece a urgência do desenvolvimento da consciência ecológica que não dissocia natureza e cultura, homem e animal.

Em sua "Introdução", Morin aponta que a crise trazida pela pandemia trouxe à luz a relação de interdependência da humanidade e que o fenômeno, na verdade, é um somatório de crises que já estavam em curso, quais sejam: políticas, econômicas, sociais, ecológicas, nacionais e planetárias. O pensador francês retoma o conceito de complexidade, tão caro em sua obra, indicando a necessidade de uma mudança de Via (ideia que será retomada e desenvolvida nos capítulos

\footnotetext{
${ }^{1}$ Pós-graduando em Psicopedagogia (Instituto Sedes Sapientiae). Professor de Língua Portuguesa (Rede Pública Municipal de Mogi das Cruzes). Psicólogo (CRP 06/161.507). Licenciado em Letras (USP) e Pedagogia (UNINOVE). Bacharel em Psicologia (UMC).
} 
seguintes), para que haja a regeneração da política, a proteção do planeta e a humanização da sociedade.

No primeiro capítulo, "As 15 lições do coronavírus", o pensador francês, em um estilo já conhecido pelos seus leitores, enumera as reflexões trazidas pela pandemia. Morin descreve a existência humana, com suas fragilidades e precariedades, distante do essencial e, principalmente, da aceitação da incerteza como uma característica imanente a ela. O filósofo proclama a quebra do mito ocidental de homem como senhor e dono da Natureza, em lugar de uma consciência ecológica que precisa ser desenvolvida com urgência. Tal fragilidade obriga a humanidade a entrar em contato com a morte, com a difícil tarefa de lidar com as restrições públicas a cerimônias e rituais fúnebres.

O isolamento social, medida emergencial e obrigatória para conter a contaminação do coronavírus, também foi visto por Morin de forma otimista, seja pela possibilidade de se desintoxicar de práticas consumistas, seja pelo ressurgimento da solidariedade em muitos locais e países. A valorização dos serviços essenciais foi acompanhada da desigualdade socioespacial que se explicitou na pandemia, bem como da diversidade na condução das medidas sanitárias de prevenção contra o coronavírus. O autor considera a crise um momento que pode levar a retrocessos, mas também a progressos, pelo estímulo à imaginação e à criatividade humanas. Vivenciamos essa criatividade em nosso sistema educacional que, migrando do atendimento presencial para o remoto, adequou seu processo de ensino e aprendizagem ao distanciamento social.

Defensor da visão sistêmica do conhecimento, Morin lamenta o posicionamento da Ciência que, competitiva, valoriza a hiperespecialização e o mensurável, prejudicando a percepção do todo e o exercício de síntese. O filósofo associa essa visão à forma fragmentada como o conhecimento é transmitido, refletindo-se na configuração das esferas sanitária, econômica, ecológica, nacional e mundial.

A respeito de política, o autor de Os Sete Saberes para a Educação do Futuro critica a valorização da economia, da doutrina da livre concorrência, assim como o excesso de burocratização do Estado, e a privatização dos serviços públicos. Ao recorrer à mão-de-obra barata, sistemas nacionais como a agricultura e pecuária de pequeno porte foram desvalorizados. A globalização é posta em xeque pelo fato de, em sua defesa, dar mais importância à industrialização dos modos de produção, ameaçando o ecossistema.

No segundo capítulo, "Desafio do pós-corona", Morin, dialogando com o capítulo anterior, elenca os desafios futuros para a humanidade, tendo sobrevivido à pandemia do coronavírus. Composto, predominantemente, de perguntas sem respostas, o texto traz reflexões sobre a aceleração do tempo, a valorização de práticas solidárias, a urgência em reinventar a política, fortalecendo os serviços públicos e desburocratizando a máquina estatal. A democracia também é sua preocupação, pelo fato de a liberdade ter sido ameaçada com as medidas restritivas de propagação do coronavírus e os avanços tecnológicos para o rastreamento e vigilância de pessoas. 0 filósofo francês alerta para a criação de uma medida autossuficiente de produtos ligados à saúde e à alimentação, com vistas ao fortalecimento da economia nacional e local, além do exercício da proteção ecológica, requerendo mudança de hábitos. No entanto, ele não se omite quanto ao perigo de haver, no futuro, retrocessos que levem à formação de Estados neo autoritários e neo totalitários.

É no quarto capítulo, "Mudar de Via", que Morin apresenta sugestões para a mudança de paradigmas em nível mundial. Retomando o conceito elaborado na obra de 2011, A via: para o futuro da humanidade, o autor elucida que esse termo é mais próximo da ideia de dinamismo que pretende transmitir aos leitores. A favor da regeneração da política e da humanização da sociedade, idealiza uma nova "Via político-ecológico-econômico-social", propondo a conjunção dos opostos, como globalização e desglobalização, crescimento e decrescimento, desenvolvimento e envolvimento. 
Ao propor um exercício de consciência, o autor sugere o diálogo entre os agentes sociais, levando à efetiva participação democrática, ao fortalecimento da economia das necessidades essenciais, ao revigoramento da comunidade e da solidariedade. Para ele, não é possível propor uma radical transformação por meio de uma violenta revolução, mas sim, por um claro exame das teorias políticas existentes, selecionando elementos que contribuam para a construção de uma ética pessoal de responsabilidade. Dessa forma, haverá a reumanização da sociedade. No binômio Eu-Nós, Morin professa não a anulação do indivíduo, mas sim seu fortalecimento como parte integrante de um coletivo que deve aprender a conviver de forma afetiva, conscientizando-se de que é também parte do planeta e da natureza, o que o autor resumiu na expressão "comunhão de destinos terrestres".

A formação do que chama de Homo Complexus, ambíguo e instável, que soma razão e paixão deve-se ao acolhimento e à união de opostos, na tentativa de desenvolver a solidariedade e a responsabilidade, sem deixar de lado a poética do amor, a comunhão e o encantamento estético. A proposta de Morin é realista e, ao mesmo tempo, utópica, pois abre espaço para modificar o presente, pensando em suas possibilidades futuras. Seu ideal abre-se para o exercício permanente da regeneração, para a prática constante do metamorfosear-se.

$\mathrm{Na}$ "Conclusão", Morin apresenta uma ampliação da percepção da história encontrada em seu "Preâmbulo", para o coletivo, pois reitera que a pandemia do coronavírus é o resultado de uma crise planetária da humanidade, devendo ser tratada como tal, pois fazemos parte de um organismo vivo, nossa "mátria terrestre".

Por fim, não poderíamos deixar de relacionar a visão de esperança trazida por Morin e aquela professada pelo educador brasileiro Paulo Freire, cujo centenário de nascimento também é comemorado no ano de publicação desta resenha. Em ambos, a esperança não está longe do risco e do imprevisto que acompanham o desejo de regeneração e de aspiração a uma outra vida e a um outro mundo: "Esperança não é certeza, traz consciência dos perigos e das ameaças, mas nos faz tomar partido e fazer apostas" (MORIN, 2021, p. 94). 